\title{
MICROBIOLOGICAL EVALUATION OF DOMLATE CHEESE IN MANSOURA CITY
}

\author{
Tbrahim, M. Aman*; Maha, A. M. Al-Ashmawy**; \\ Ahmed, A. El-Gamal*"* and Arwa, H. M. Nassar"** \\ -Food Control Depl., Faculty of vel. Med., Kafr El-Shelkh University \\ * Food Control Dept., Faculty of vet. Med., Mansoura Unlversity \\ - Anlmal Health Regearch Institute- Mansoura
}

\begin{abstract}
A total of one hundred random samples. of Domiate cheese (white soft cheese) were collected from different lacalities in Mansoura city, El-Dakhalia Governorate to be exam. ined for the incidence of total aerobic count, Coliforms. True faecal type E.coli . Staph. aureus and total mould and yeast count.

The obtained results revealed that the mean value was $1.9 \times 10^{6}-1.6 \times 10^{5}$. $1.5 \times 10^{4}$.

$7.2 \times 10^{4}$ and $4.6 \times 10^{4}$ of the examined samptes, respectively. Whille their incldence were $100,69,45,64$ and $88 \%$ of the collected samples, respectively. Grading examined Domlate cheese according to Egyptian standard for total collfonis count, The faecal type E.coli. Staph. aureus and total mould and yeast count fourld the percent of acceptable samples were $54 \%, 55 \%, 36 \%$ and $22 \%$ from the total examined samples. respectlvely, while unacceptable sample were 46, 45, 64 and $88 \%$ of examined samples, respectively. Grading of examined Domiate cheese according to UK Microbiological standard were 59\%, 97\%, 79\% of samples are satisfactory for total Staph aureus, E.coli and coliforms count respectlvely, while $41 \%, 3 \%$ and $21 \%$ of samples are un satisfactory, respectively.

The public health signifurance and econonmic importance of isolated organisms as well as recommendation for prevention and minimizing the microbial contamination of Dorniate cheese were also discussed.
\end{abstract}

\section{INTRODUCTION}

Cheese was onginally developed as a mean of preserving raw milk in time of exccss production and generally considered to be relatively safe food, cheese contalns high quality protelns, vital minerals aud vitamins. However. the spread of some diseases by cheese have been demonstrated. Whyst pathogens can gain access to cheese from raw milk and post processing. It is clear that many food bome pathogens are faecal in origin.

The higher total baeterlal count in white soft checse samples were occured due to 
several factors as post pasteurization contamination, usually through eontact with equipment surfaees or from the alr and bioflms residing on surfaces Wustin and Bergeron, 1995).

The presence of large number of collform in cheese is highly undesirable because it was imposslble to eliminate from food. The presence of True faecal type E.eoll in cheese samples is an indication of fecal conlamination. Moreover. these organisms can grow in cheesc especially in hot climatic conditlons resulting in undesirable changes in the product besides they constitute a public health hazard.

Staphylococcal lood polsoning is being reported with increasing frequency especially in developing countries where food hygienc is still underway (Anne-Galle et al. 2005) .

Yeast and mould count in cheese are used as Index of proper sanitation quadity. Defects in these undpened soft cheeses as rancldity, softness and color defects arise malnly from contamination by yeast and mould.

\section{MATERIALS AND METHODS}

One hundred random samples of soit cheese (Domlate cheese) were collected from different markets and dairy shops in Mansoura clty EL-Dakhlia Prownce. Each sample was represented by about 100-150 grams of cheese which was appeared In normal characteristics properties (navor, aroma, appearance and texture). The collected samples werc uransferred to the laboratory in clean. dry. sterile and ughtly closed wide mouth Jars. with a minimum of delay, where they were prepared for microblological examination.

\section{Bactertological examinatlon:}

(A) Preparation of serial dilutions (APHA, 1992).

(B) Aerobic plate count (Harrigan, 1998).

(C) Most probable Number of Coliforms (Harrigad, 1998).

(D) Count of True faecal type E.coll by muluplc tubc tcchnique (Harrigan, 1998).

(E) Staphylococcus aureus count (Harrgan, 1998).

(F) Total Yeast and mould count (Roberts et al., 1995).

\section{RESULTS AND DISCUSSION}

The results glven in Table (1) revealed that the total aeroblc count of examined eheese samples ranged from $1 \times 10^{3}$ to $6.3 \times 10^{7}$ with a mean value of $1.9 \times 10^{6} \pm 0.68 \times 10^{6}$.

Inspection of Tablc (1) Fig. (1) Indicate that the incidence of acrobic bacterla were $100 \%$. The highest frequency distribution lay with in the range of $10^{4}-10^{6}(67 \%)$. Table (2) flg. (2).

Total aerobic mesophilic count is a prime consideration in examination of food and glves a numerical flgure that helping in assessing the general hygienic quality of the product. It reflects the sanitary measurcs adopted during production. handling and storage (ICMSF, 1986).

The colliorm count (MPN $\backslash g$ ) ranged from $0.9 \times 10$ to $1.4 \times 10^{7}$ with a mean value of $1.6 \times 10^{5} \pm 1.4 \times 10^{5}$. According to results presented in Table (1) and Fig. (1) 69\% of examIned cheese samples were contaminated by collform bactera. The highest frequency 
distribution were $(48 \%)$ lay with in the rang of $10-10^{4}$ Table (2) Fig. (2).

Collform counts are traditional indieator of possible faecal contamination, microblal qualIty and refleet the hygienic standards adopted In the dairy processing (Ozdemir et al. 1998). A lake of good sanitary pracuces may result in a loss of quailty. spollage or in some cases create a health hazard.

The statisucal analytical results reported in Table (1) revealed that True faecal type E.coll count in examined samples ranged from $0.4 \times 10$ to $1.5 \times 10^{6}$ CFU⿺g with a mean value of $1.5 \times 10^{4} \pm 1.4 \times 10^{4} \mathrm{CFU} \backslash \mathrm{g}$.

The highest frequency distribution (25\%) lay with in the rang of $10^{2}-10^{4}$ Table (2) Fig. (2). The results given in Table (1) and Fig. (1) showed that true fecal type E.colf was Isolated from $45 \%$ of examined Domlate cheese samples.

Escherichla coll was one of thc most Important food - borne pathogens that are widely distributed throughout the cnvironment. They have been associated with sever food polsoning outbreaks (Condera et al. 2004) .

The count of Staph aureus was found to be ranged from $1 \times 10^{2}$ to $3.6 \times 10^{6}$ with a mean value of $7.2 \times 10^{4} \pm 3.8 \times 10^{4}$ Table (1)

According to the results represented In Table (1). Fig (1) $64 \%$ of examined Domlate cheese samples were contaminated by Staph. aureus. The highest frequency distribution (40\%) lay within the range of $10^{4}-10^{6}$ Table (2) Flg. (2). Moreover. Staphylococcus aureus have been found in varlous type of cheese and involved in outbreaks of food polsoning (De Reu et al. , 2002).

The statistical analytieal results reported in Table (1) revealed that total mould and yeast count in examined samples ranged from $1 \times 10^{2}$ to $8.3 \times 10^{5} \mathrm{CFU}$ g with a mean value of $4.6 \times 10^{4} \pm 1.1 \times 10^{4}$ CFUIg .

The highest frequency distribution $51 \%$ lay within the rang of $10^{2}-10^{4}$ Table (2) Fig. (2) Results given in Table (1) indicate that $88 \%$ of examined cheese sainples were contaminated with mould and yeast.

The results obtained Indicated that the Domlate cheese in Mansoura City was manufactured and handled under neglected santtary measures. Therefore strict hygienic measures should be adopted during production of such valuable product .

Grading of the examined Domlate cheese accordlng to the Egyptian Standard (2005) :

The data 1llustrated in Table (3) explained that grading of cheese according to total coliform count were as follow $54 \%$ met the acceptable levels and $46 \%$ unacceptable

Grading of examined samples according to True raccal type E.colf Indlcated that most of the samples $55 \%$ were acceptable levcls but $45 \%$ of samples were unacceptable .

Grading of examined samples according to Staph. aureus count showed that $64 \%$ of samples were unacceptable and $36 \%$ were aeceptable . 
Grading according to total mould and yeast count found that $22 \%$ met the acceptable $11 \mathrm{~m}$ it and $88 \%$ of the examined Domlate cheese samples unacceptable.

Grading of examined Domlate cheese samples according to UK. Microblological Guldelines (Roberte et al., 1996) :

By comparing the bacterlal count of the examIned Domlate cheese samples with UK. Microbiological Guidelines found that 59\% \& $97 \%$ of samples werc satisfactory for Staph. aureus \& True faeeal type E.coll count respectvely, Table (4). Furthermore 41\% \& $3 \%$ of examined samples are unsatisfactory for Staph. aureus \& True faecal type E.coll count. respectively. While incase of total coliform $79 \%$ of samples were satisfactory but $21 \%$ of samples were unsatisfaetory.
Fortunately, absence of Staph aureus or True faecal type E.coll indicaung either good sanitation or that these bacterla is not a good eormpettor with other bacterla present, also presenee of E.colt in cheese is objeetional not only, it renders cheese unft for human consumption but also, its presencc is a rellable Index of faecal contamination, it can enter cheese by many ways as milk, contaminated utenslls, water, flies and handling.

Domlate cheese is an excellent medium for the growth of microorganlsm duc to its compositional and high nutritive value, it is an Important dairy product and an integral part of a healthful diet due to its substantial contribution to human health so that presence of pathogens in cheese is objectional and lead to potentral health hazards to rood safety and human health . 
Brahim, M. Aman; et al...

Figure (1) . Incldence of leolated micro-arganleme from Domiate cheosesamples
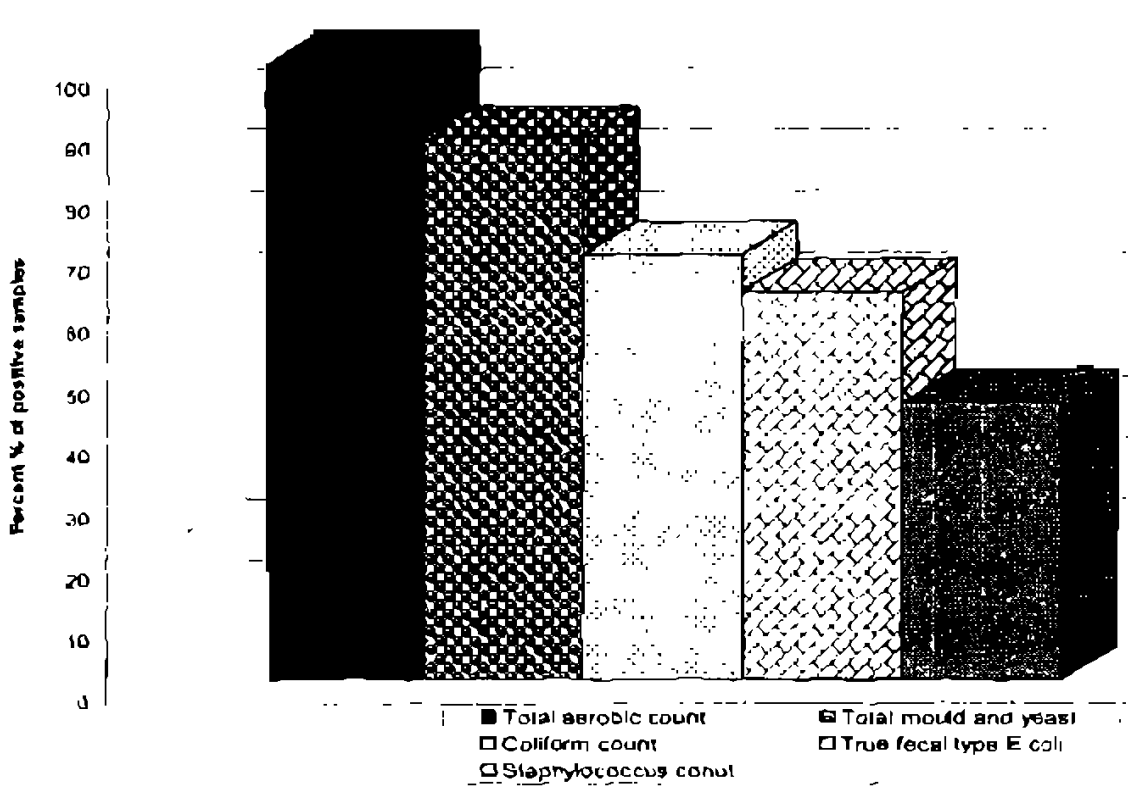

Table (1): Statistical analytical results of Microbial count of examined Domiate cheese samples.

\begin{tabular}{|l|c|c|c|c|c|c|}
\hline Microbial Count & $\begin{array}{c}\text { No. of } \\
\text { examined } \\
\text { samples }\end{array}$ & $\begin{array}{c}\text { No. of } \\
\text { posifive } \\
\text { samples }\end{array}$ & Min. & Max. & Mean & \pm S.E.M. \\
\hline Total aerobic count & 100 & 100 & $1 \times 10^{3}$ & $6.3 \times 10^{7}$ & $1.9 \times 10^{6}$ & $0.68 \times 10^{10}$ \\
\hline Coliform count & 100 & 69 & $0.9 \times 10$ & $1.4 \times 10^{7}$ & $1.6 \times 10^{5}$ & $1.4 \times 10^{5}$ \\
\hline True fecal type E.coli & 100 & 45 & $0.4 \times 10$ & $1.5 \times 10^{6}$ & $1.5 \times 10^{4}$ & $1.4 \times 10^{4}$ \\
\hline $\begin{array}{l}\text { Staphylococcus } \\
\text { aureus count }\end{array}$ & 100 & 64 & $1 \times 10^{2}$ & $3.6 \times 10^{6}$ & $7.2 \times 10^{4}$ & $3.8 \times 10^{2}$ \\
\hline Mould and yeast count & 100 & 88 & $1 \times 10^{2}$ & $8.3 \times 10^{3}$ & $4.6 \times 10^{4}$ & $1.1 \times 10^{4}$ \\
\hline
\end{tabular}

Mansoura, Vet. Med. J.

Vol. XI. No. 2, 2009 
Bbrahim, M. Aman; el al...

Table (2): Frequency distribution of examined Domiate cheese samples based on their bacterial count .

\begin{tabular}{|c|c|c|c|c|c|}
\hline \multirow[b]{2}{*}{ Interval } & \multicolumn{5}{|c|}{ No of positive samples } \\
\hline & $\begin{array}{l}\text { Toral } \\
\text { colony } \\
\text { count }\end{array}$ & $\begin{array}{l}\text { coliform } \\
\text { count }\end{array}$ & $\begin{array}{l}\text { True faecal } \\
\text { type E.coli }\end{array}$ & $\begin{array}{l}\text { Siaph. } \\
\text { aureus }\end{array}$ & $\begin{array}{l}\text { mould and yeast } \\
\text { count }\end{array}$ \\
\hline $10-<10^{x}$ & - & 23 & 17 & - & - \\
\hline $10^{2}-<10^{4}$ & 2 & 25 & 25 & 23 & \$! \\
\hline $10^{4}-<10^{6}$ & 67 & 19 & 2 & 40 & 37 \\
\hline $10^{6}-\leq 10^{4}$ & 31 & $\underline{2}$ & 1 & I & - \\
\hline Totgl & 100 & 69 & 45 & 64 & 88 \\
\hline
\end{tabular}

Table (3) : The bacterial results of Domiate cheese samples as compared with Egyptian standards (2005).

\begin{tabular}{|c|c|c|c|c|c|}
\hline Test & $\begin{array}{l}\text { No. of examined } \\
\text { sumples }\end{array}$ & \multicolumn{2}{|c|}{$\begin{array}{c}\text { Acceptable } \\
\text { (covering negative results) }\end{array}$} & \multicolumn{2}{|c|}{ Unacceptuble } \\
\hline \multirow{3}{*}{ Tolal coliform counl } & \multirow{3}{*}{100} & \multicolumn{2}{|c|}{$<10$} & \multicolumn{2}{|c|}{$>10$} \\
\hline & & No. & $\%$ & No. & $\%$ \\
\hline & & 54 & 54 & 46 & 46 \\
\hline \multirow{3}{*}{ Total E. coli count } & \multirow{3}{*}{100} & \multicolumn{2}{|c|}{ Frue from $E$. coli } & \multicolumn{2}{|c|}{ Presence of E.coli } \\
\hline & & No. & $\%$ & No. & $\%$ \\
\hline & & 55 & 55 & 45 & $45^{-}$ \\
\hline \multirow{3}{*}{ Total Staph. aureus } & \multirow{3}{*}{100} & \multicolumn{2}{|c|}{ Free from Siaph. aureus } & \multicolumn{2}{|c|}{ Presence of Staph. aureus } \\
\hline & & No & $\%$ & No. & $\%$ \\
\hline & & 36 & 36 & 64 & 64 \\
\hline \multirow{3}{*}{$\begin{array}{l}\text { T'otal Mould and } \\
\text { Yeast count }\end{array}$} & \multirow{3}{*}{100} & \multicolumn{2}{|c|}{$\begin{array}{l}\text { Mould }<10 \\
\text { yeast }<4 \times 10^{2}\end{array}$} & \multicolumn{2}{|c|}{$\begin{array}{r}\text { Mould }>10^{\circ} \\
\text { yeast }>4 \times 10^{2}\end{array}$} \\
\hline & & No. & $\%$ & No. & $\%$ \\
\hline & & 22 & 22 & 88 & 88 \\
\hline
\end{tabular}


Ibrahim, M. Aman; et al...

Table (4): Grading of examined Doniate clieese samples yccording to UK Micrabiological Guidelines (Roberts et al., 1995).

\begin{tabular}{|c|c|c|c|c|c|}
\hline Test & $\begin{array}{c}\text { No. of } \\
\text { examined } \\
\text { samples }\end{array}$ & \multicolumn{2}{|c|}{ Satis[actory } & \multicolumn{2}{|c|}{ Unsatisfactory } \\
\hline \multirow{3}{*}{$\begin{array}{c}\text { Total Sraph. } \\
\text { aureus }\end{array}$} & \multirow{3}{*}{100} & \multicolumn{2}{|c|}{$<10^{3}$} & \multicolumn{2}{|c|}{$>10^{4}$} \\
\hline & & No. & $\%$ & No. & $\%$ \\
\hline & & 59 & 59 & 41 & 41 \\
\hline \multirow{3}{*}{$\begin{array}{c}\text { Total } E \text {.coli } \\
\text { count }\end{array}$} & \multirow{3}{*}{100} & \multicolumn{2}{|c|}{$>10^{4}$} & \multicolumn{2}{|c|}{$>10^{5}$} \\
\hline & & No. & $\%$ & $\mathrm{Na}$. & $1 \%$ \\
\hline & & 97 & 97 & 3 & 3 \\
\hline \multirow{3}{*}{ Total coliform } & \multirow{3}{*}{100} & \multicolumn{2}{|c|}{$<10^{4}$} & \multicolumn{2}{|c|}{$>10^{4}$} \\
\hline & & No. & $\%$ & No. & $\%$ \\
\hline & & 79 & 79 & 21 & 21 \\
\hline
\end{tabular}

Figure (2) Microbial contaminalion of the examined Domiate cheese

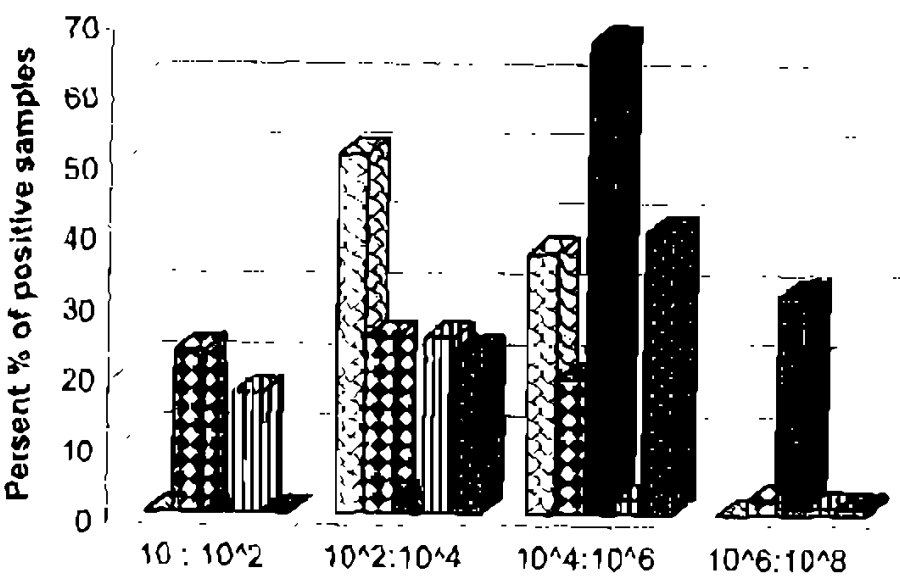

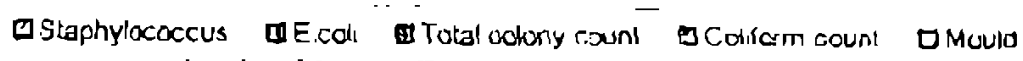




\section{REFERENCES}

American Public Health Assoclation (APFLA. (1902) : Compendium of methods for the microblological examination of food 3rd ed., Vander Zant.C. ans spllttstoesser, D.F. (eds) . Washington, D.C.

Anne- Galle, L.; Katlanna, 3.; Joel Dore, P.: Prancols, C. and Tholozan. J. (2005): Development and validation of PCR primers to Asses the Divcrsity of Staphyloccoct in cheese. by Temprol temperature Gradient Gel Electrophoresis. Applied Environ. Microbiol J., 71 (1) : 29-38 .

Austin, J. W. and Bergeron, C. (1995) : Development of bacterlal bloflms in dalry proceccing lines. J. of Dalry Res., 62: 509 . 519.

Condera, G.; Dalvit, P.; Martinl, M.; Galero, G.; Garmaglia, M.; Goffredo, E.; Loffredo, G.; Morablto, S.; Sempronl, P.; Ottavinl. D.: Paterlinl, F.; Pezzett, G.; Plbanu, M. and Caprioll, A (2004) : Verocytotoxogenlc -producing Escherichla coll $\mathrm{O} 157 ; \mathrm{H}$ ? in minced beef and dalry products in Italy . Ine. J. of food Microbial. 96:67-73.

De Reu. K.; Debeuckelaere, w.; Bottel- doom, N.; De Block, J. and Herman, $L$. (2002) : Hygienic parameters, toxdns and pathogens occurrence in raw millk cheeses. J. Food safety, PP. 22.

EGSB, Egyptian standards for soft cheese - Domiate cheese (2005) : part 3 Es. 1008 - 3\} 2 0 0 5 .

Harrigan, W. F. (1998) : Laboratory methods in food microblology, 3rd ed. Acadernic press, San Dlego, London, Boston, New York. Sydney, Tokyo, Toronto.

ICMSF, (1986) : International Commlssion on Microblological Speciflcation Microblology of Food and sampling for microblological analysls principals and specinc applications . 2 Ed. Academic Press, New York, London .

Ozdemir, S.: Cellk, C. and Sert, $M$. (1098) : The microblologlcal and chemical propertites of Orgu chcese produced In Karacadag reglon of Dlyarbakir. Tturkey . Intemational productuvity center publ. No. 66

Roberts. D.; Hooper, w. and Greenwood, M. (1998) : Practical food microbiology. Public Health Laboratory Service. London .2nd EdtUun. 
اللنخص العربى

\section{التقييم الميكروبيولوجى للجبن الدمياطى فى مدينة النصورة}

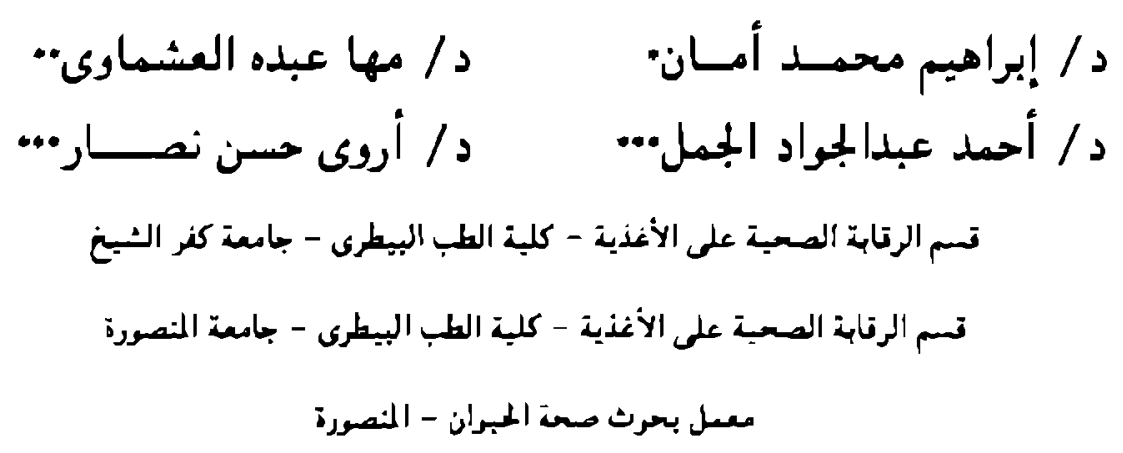

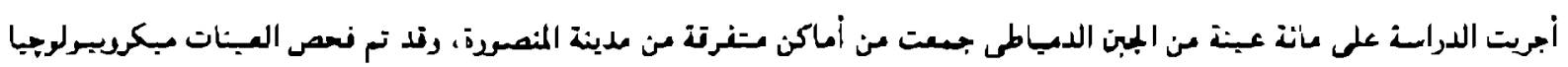

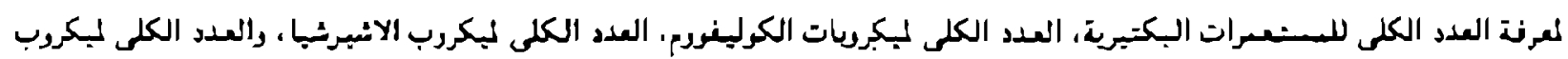

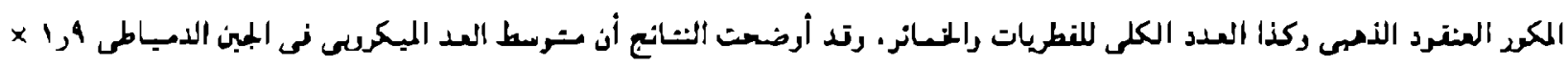

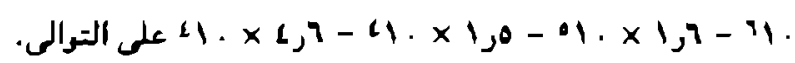

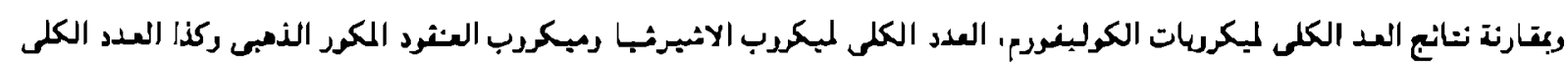

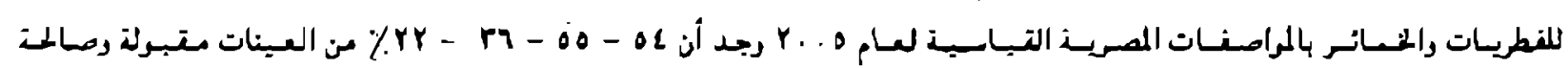

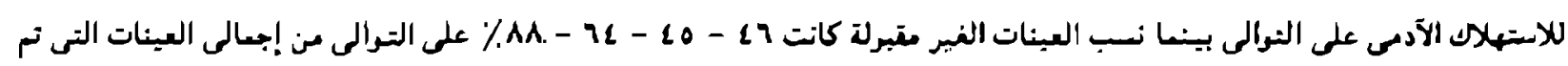

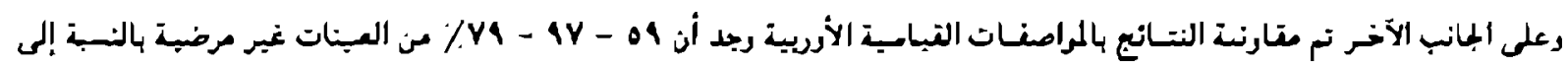

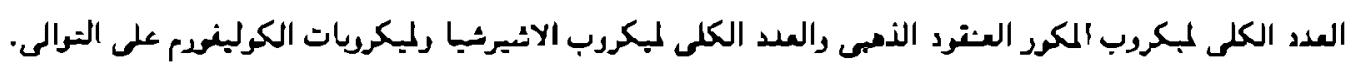

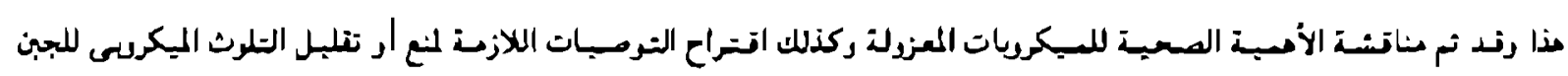

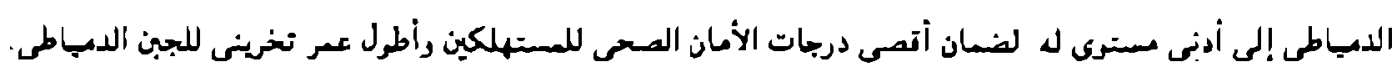

